\title{
A COMPARISON: TRANSLATED HOMOSEXUAL- THEMED NOVELS IN ESTADO NOVO PORTUGAL AND STATE-SOCIALIST HUNGARY ${ }^{\prime}$ UMA COMPARAÇÃO: ROMANCES TRADUZIDOS DE TEMÁTICA HOMOSSEXUAL NO ESTADO NOVO PORTUGUÊS E NO ESTADO SOCIALISTA HÚNGARO
}

\section{ZSOFIA GOMBAR*}

\begin{abstract}
The present article aims to contribute to homosexual history by mapping queer literary translations in Estado Novo Portugal and Socialist Hungary. In view of the legal and censorial dissimilarities in the two countries with regard to same-sex activity, homosexual-themed literature translated from English has been examined in order to detect any possible divergence or convergence in this respect. The analysis also relied on book censorship files stored at the National Archives of the Torre do Tombo as well as the new findings of the Hungarian project English-Language Literature and Censorship, 1945-1989.
\end{abstract}

Keywords: censorship, translation production, Estado Novo Portugal, state-socialist Hungary.

RESUMO: O presente artigo pretende contribuir para a história de homossexualidade mapeando as traduções literárias durante o Estado Novo em Portugal e o comunismo na Hungria. Tendo em vista as diferentes práticas legais e censórias nos dois países em relação à homossexualidade, literatura de expressão inglesa traduzida foi examinada a fim de detectar divergências ou convergências possíveis. Além disso, a análise baseiase nos ficheiros de censura armazenados no Arquivo Nacional da Torre do Tombo, bem como nas novas descobertas do projeto húngaro English-Language Literature and Censorship, 1945-1989.

Palavras-chave: censura, obras traduzidas, Estado Novo Portugal, Estado Socialista Hungria.

\footnotetext{
${ }^{1}$ The research work was conducted in the context of my post-doctoral project "English-Language Literature and Censorship in Portugal and Hungary during the Second Half of the Twentieth Century" supervised by Teresa Seruya, Alexandra Assis Rosa, and Patricia Odber de Baubeta, and funded by the Portuguese Foundation of Science and Technology (FCT) (SFRH/BPD/92486/2013). * Research Group on Reception and Translation Studies Centro de Estudos Anglísticos, da Faculdade de Letras, Universidade de Lisboa.
} 


\section{ntroduction}

Besides the arbitrary coincidence of sharing the same size and population, continental Portugal and Hungary seemingly are two distinct countries in cultural and linguistic terms. Nonetheless, the fact that both of them were governed by opposing dictatorial regimes in the twentieth century provides an excellent ground for comparison. The comparative aspect of the present analysis is rooted in the need to promote a dialogue between cultures of different historical and political heritages as opposed to studies on a particular country in a particular period. Seeing the contrasts between the Portuguese and Hungarian regimes' social, political and cultural policies and practices may provide us with a more detailed insight into the two countries' overall attitude towards same-sex behaviour.

In comparison to the persecution of homosexuals in Hitler's Germany or in Stalin's Russia, but also in supposedly democratic Australia, both the Portuguese and Hungarian dictatorial regimes' attitude towards same-sex relations appear relatively lenient. For instance, despite Portugal's initial pro-Nazi sympathies as well as totalitarian traits (cf.: ROSAS, 1992, PAYNE, 1996; PINTO, 1995; TORGAL, 2009 and PINTO and KALLIS, 2014), homosexuality was never planned to be completely eradicated from society-as in the Third Reich (for further information on the Nazi period, see PLANT, 1986; GRAU, 1995; SPURLIN, 2009). Even if detentions, incarcerations as well as psychiatric confinements did occur in Estado Novo Portugal, deportation and killings of homosexuals was intrinsically alien to the norms and values underlying Salazar's visions for Portugal. Moreover, unlike in Stalin's Russia, there were no mass arrests of homosexuals in the People's Republic of Hungary, either (cf. HEALEY, 2004 and BAER, 2011).

In light of the historical fact that "buggery" (anal intercourse) in certain circumstances was punishable by mandatory death in Australian state Victoria until 1949-changed to 20-year imprisonment, later downgraded to 15 years (for more information, see CARBERY, 2010 as well as WILLETT, 1997 and ROBINSON, 2008), up to 3 years' confinement in Estado Novo Portugal and 1 year in socialist Hungary until 1961 reflect a categorically more permissive attitude adopted by these governments (cf. ALBUQUERQUE, 2013; ALMEIDA, 2010; TAKÁCS and TÓTH, 2016 and TAKÁCS, KUHAR, and TÓTH, 2017). 


\section{Criminalisation and Legal History of Homosexuality}

A comparison of the legal framework for prosecution of same-sex acts in Portugal and Hungary, however, reveals considerable differences. Intriguingly, while homosexuals might have been condemned to death by burning at the stake during the Portuguese Inquisition (1536-1821), homosexuality was decriminalised in Portugal as early as 1852. It was soon recriminalized in 1886, and subsequently the Portuguese legislative system became again increasingly aggressive towards homosexuals. In 1912, already during the First Republic (1910-1926), a new legal category vádio [vagrant] was introduced in the Penal Code, which besides homosexuals, included prostitutes, pimps, mendicants and other street people (ALMEIDA, 2010, pp. 65-70). In legal terms, homosexuality along with prostitution, mendicancy, and poverty was regarded as a social menace and a potential threat to public order and safety. The exclusion and intimidation of these disgraceful and potentially dangerous members of society also suited the new authoritarian regime's interests. The infamous Mitra penitentiary, where the majority of convicted male homosexuals were transferred, was founded in 1933, already under the Estado Novo regime (1933-1974) (for more information on anti-homosexual legislation in Portugal see CASCAIS, 2016).

In Hungary, sodomy between same-sex males was also a death crime until the beginning of the $18^{\text {th }}$ century (for case studies, see ESZENYI, 1999). According to the Hungarian Penal Code of 1878, however, sexual acts between men were only punishable by up to one year's incarceration (TAKÁCS, 2017, p. 157). This Code remained in force during Horthy's conservative regency (1920-1944) as well as the Stalinist Rákosi regime (1949-1956). The Kádár administration (1956-1989) that followed the defeat of the 1956 Revolution brought ideological relaxation and also permitted more freedom in the private sphere. Indeed, Hungary, preceding the Soviet Union (Russia, 1993) and its satellite states such Bulgaria (1968), Romania (2001), Albania (1995) and also several Western democratic countries including the USA (1962/2003), Canada (1969), United Kingdom (1967/1981/1982), and Ireland (1993), decriminalised consensual sexual activity between same-sex adults in 1961 (for more information, please consult: http:// www.equaldex.com).

The unprecedented decriminalisation of homosexuality in socialist Hungary apparently stands in sharp contrast with the Estado Novo's occasionally obscu- 
re and unregulated legal practices along with the totalitarian Rákosi regime's irrationally inhumane repressive policies. A recently discovered archival record of 1958 suggests that the decriminalisation process was initiated by a petition filed by an unnamed individual-presumably a homosexual man - which should be considered a very unusual case in the Eastern Bloc territory. Moreover, the amendment seems to have been decisively influenced by the decision of a medical (in this case a psychiatric) committee (TAKÁCS and TÓTH 2016: 207-223).

The conceptual change of homosexuality from crime to illness seemingly followed the same pan-European pattern in both countries. From the $19^{\text {th }}$ century on, homosexuality ceased to be seen only as a religious or moral sin, but more of an in-born or acquired mental disorder (a medical problem). Despite its stigmatising and pathologising potential, the medicalisation approach would accelerate worldwide legal reforms, inasmuch as if same-sex orientation was defined as a congenital and hereditary condition, homosexuality should come under psychiatric care rather then legal prosecution. Nonetheless, the impulse to punish, or at least, regulate and repress sexual minorities would persist in both the Portuguese and Hungarian legislative systems until the change of the regimes.

Importantly, Takács and Tóth calls attention to the fact that decriminalisation of homosexuality did not effect radical changes in public attitude towards homosexuality in Hungary. The prevailing stigmatisation of homosexuality in Hungary still forced homosexuals to publicly hide their sexual orientation and live a highly closeted life (2016, p. 239). Also, the different ages of consent for same-sex relationships ${ }^{1}$ as well as the limitation clause on scandalous homosexual behaviour $^{2}$ introduced into the Penal Code in 1961-punishable by up to three years' imprisonment-continued to provide legal grounds for the authorities to keep assumed homosexual citizens under strict control. Archival evidence suggests that decriminalisation of same-sex activity did not prevent the police from the

\footnotetext{
${ }^{2}$ The age of consent for homosexuals was raised to 20 years, and reduced to 18 in 1978, while the age of consent for heterosexual acts had been 14 since 1961 .

${ }^{3}$ The special clause specified that "perversion against nature conducted in a scandalous manner" should be publishable by up to 3 years of imprisonment. Even though the law did not specify the term "scandalous", according to the court reports currently stored at the Budapest City Archives, the clause was mostly applied, if a third party could have witnessed the sexual act (TAKÁCS, 2017, p. 166).
} 
compilation of homosexual inventories of possible homosexual blackmail victims and of course of potential police informers (TAKÁCS, 2015, pp. 169-170 and KURIMAY and TAKÁCS, 2017, p. 589).

On the whole, it must be said that although Portugal appears to have a harsher punitive system in comparison to Kádár-regime Hungary, homosexuals were persecuted in both countries throughout the era. It should be added though that both administrations seem to be remarkably tolerant towards homosexual behaviour if it remained socially invisible. Compared to the Holocaust or Soviet oppression of sexual minorities, persecution of Portuguese and Hungarian homosexuals was less violent and more restricted in its range.

Moreover, not all homosexuals were treated equally in the two countries. In Portugal the punishment measures adopted might have been at great variance depending on the person's political inclination or social status. Being an appreciated friend of the regime or member of the social elite might have provided protection from legal sanctions (cf. ALMEIDA, 2010). This was also partly true in Hungary. The court cases, albeit fragmentary, for the socialist period examined by Takács and Tóth, for instance, reveal that the overwhelming majority of the defendants were, so-to-say, ordinary people. It is also expected that homosexual persons occupying positions of political power were less likely to be among the defendants in court cases (TAKÁCS, KUHAR, and TÓTH, 2017, p. 1957).

\section{Censorship and Homosexuality}

As far as the artistic representations of same-sex desire are concerned, homosexuality along with nudism, prostitution, abortion, mental illness, infant mortality, suicide, were regarded as a strict taboo, and a mere reference to any of these topics could lead to the prohibition or mutilation of the work in question (BARRETO and MÓNICA, 1999, p. 275). Although the Constitution of 1949 declared that censorship did not exist in Hungary, books, stage plays, films along with newspapers and journals were indeed censored if they were deemed to be politically or morally detrimental to the public.

The most notable difference that may strike the researcher when comparing Portuguese and Hungarian censorship practices is the abundance of bureaucratic documents, files, reports, and registration books issued by the Portuguese 
censorship bodies versus the almost complete lack of written records on the existence of censorship in state-socialist Hungary. The reason for this lies in the fact that Hungarian authorities consciously avoided written policies and documents and, if possible, confined themselves only to verbal directives (GOMBÁR, 2011, p. 106).

With reference to book censorship, the modus operandi also diverges substantially in the two countries. Contrary to press, theatre, cinema, radio or television censorship, non-periodical publications were subject to repressive censorship instead of prior restraint in Portugal. Post-publication censorship was far less systematic -and even if confiscation of books after being published could force the publishing house into bankruptcy-left more leeway for the publisher to publish contentious works that would pass unnoticed.

In Hungary, after Rákosi's takeover in 1948, the book publishing as well as selling industry was soon nationalised and thus came under full political control. From 1948 every publisher and printing house was obliged to submit all manuscripts to a book committee before publishing. After the 1956 Revolution the practice of external censorship ceased to exist. Paradoxically enough, the whole system was astutely based on self-censorship practiced by the publishers themselves, whose job, in fact, would crucially depend on their tacit compliance with the party state (GOMBÁR, 2011, pp. 107-108). The politicisation of literary production gradually diminished, and the new political and cultural conditions of the Thaw finally allowed the publication of less favoured authors and literary tendencies.

The newly introduced culture policy, the infamous three Ts system - tilt, tür, támogat (prohibit, permit and promote) - notwithstanding its undisguised censoring character, proved to be far more permissive than the Stalinist one (KONTLER, 1999, p. 445). Certain taboos stubbornly persisted such as criticism towards the Soviet Union and its relations, the one-party system, paying tribute to the 1956 Revolution and pornography. Representation of homosexuality, if it did not entailed graphic description of sexual activity, was tolerated to some degree (BART, 2000, p. 38). In Portugal, however, according to the laws in force, it was to be prohibited. 


\section{Research Corpus, Methodology, and Bibliographical Sources}

In view of these legal and censorial dissimilarities in the two countries, the article sets out to discover what homosexual-themed literature was and was not published in Estado Novo Portugal and state-socialist Hungary. Given the constraints of space and the size of the research material, the scope of this study is confined to Anglophone novels and novellas translated and published in book form. Accordingly, other literary genres such as poetry, drama and short stories as well as non-literary works including medical and psychiatric texts, critical writings, philosophical treatises, and literary translations from English published in periodicals along with unpublished theatre translations have been excluded from the analysis.

Inspired by the Hungarian literary scholar Zoltán Csehy's methodology adopted in his monograph on Hungarian homoerotic and queer poetry (2014), a vast corpus of homosexual-themed literary works in English was compiled. Csehy's working method was primarily based on homothematics and homosociality, but it was also influenced by art historian Christopher Reed's interpretation of homosexual artistic representation strategies. Reed's matrix of interpretation consists of two main axes: the concepts of homosexuality as defined by scholars ( 1 . normal part of maturation, 2. sexual encounters: normal/deviant, 3. separate identity, and 4. performative role) and the relationship of art to homosexuality (1. explicit description of homoerotic acts or people: made by insiders or outsiders, 2. eroticised objects (in case of literature: eroticised associative description), and 3. products of sexual minorities) (2011, pp. 8-9).

The analysis has focused more on the conceptual forms such as 2 . the sexual encounters in which one person is perceived as transcending gender norms and 3. the separate homosexual identity. All works under study encompass explicit descriptions of homosexual persons, acts, or behaviour, which are given by insiders or outsiders. The portrayals are predominantly positive or neutral, but negative representations are also to be found among them such as Crassus in Howard Fast's Spartacus or the paedophile Eppes in William Styron's The Confessions of Nat Turner.

Several reference works and annotated bibliographies were consulted in search of homosexual-themed literature such as Drake's Gay Canon (1998), Bradley's A Complete Cumulative Checklist of Lesbian Variant and Homosexual Fiction 
(2012, first ed. 1960), Slide: Lost Gay Novels (2013), Gunn's bibliographies on gay male detective novels and films (2013), gay novels of Britain, Ireland and the Commonwealth (2014), and gay American novels (2016), Hurley's A Guide to Gay and Lesbian Writing in Australia (1996), Knoble's The Male Homosexual, Gay and Queer Novel in Australia as well as a library catalogue on queer Canadian literature (RAYTER and et al. 2008). Moreover, bearing in mind the vital importance of the interpretive community in the homosexual canon formation process (BAER, 2010, pp. 22-24), a great number of online community pages, among others, goodreads https://www.goodreads.com/, the Publishing Triangle http://www. publishingtriangle.org/index.asp, The Gay \& Lesbian Reading Group, and GLBT literature http://iclarkmedia.com/gaybooks/index.html were surveyed.

The corpus was then checked against the bibliographical records on literary translations published between 1949 and 1974 in Hungary and Portugal in order to detect which source texts including explicit references to homosexual content were or were not translated in the given period. The beginning year of the time span under study marks the Communists' final takeover of the Hungarian book industry, while the closing year denotes the end of the Estado Novo regime in Portugal. The chosen time frame, thus, enables us to analyse the published translations when both countries were under dictatorial rule.

As regards other bibliographical sources, the archives of the Hungarian organization: the Háttér Society for LGBTQI People in Hungary proved to be one of the most informative and illuminating sources for this study. ${ }^{3}$ The archives founded and directed by Sándor Nagy, contain an almost complete collection of homosexual-themed works as well as translations published in Hungary up to this date. Other bibliographical catalogues were also accessed such as British Books in Hungary 1945-1978, American Books in Hungary 1945-1987 (BÁNHEGYI, 1979, 1988) and Külföldi szerzők müvei Magyarországon, 1945-1970, 19711975 [Foreign Authors in Hungary, 1945-1970, 1971-1975]. In Portugal, due to the lack of all-inclusive bibliographical databases and indices, besides PORBASE, the Portuguese Union Catalogue online ${ }^{4}$ and the National Bibliography, the re-

${ }^{4}$ For more information on the society, please visit the webpage http://en.hatter.hu/ (accessed 30 November, 2017).

${ }^{5}$ For more information, see http://porbase.bnportugal.pt/ (accessed 30 November, 2017). 
search database of the Lisbon-based project, "Intercultural Literature in Portugal, 1930-2000" was methodically searched for further matches. ${ }^{5}$

Given the scarcity of tangible evidence on the existence of censorship in People's Republic Hungary, in 2009 a research project was launched involving seven teaching and research institutions: Savaria University Centre, University of Pécs, Károli Gáspár Protestant University, Pázmány Péter Catholic University, Eötvös Loránd University of Budapest, Institute of Sociology, Hungarian Academy of Sciences, and University of Lisbon Centre for English Studies. The great innovation of the project is that it combines archival research with the oral history method. The research is predominantly based on reader's reports commissioned by Európa Publishing House - a prestigious Hungarian publisher specialised on foreign literature - between 1957 and 1989 as well as on interviews with publishers, readers, and translators. The present article also draws on the findings of the project.

As contrasted to Hungary, Portuguese book censorship files are freely available to modern researchers. The reports issued between 1934 and 1974 are currently stored at the National Archives at the Torre do Tombo in Lisbon. The archive series "Relatórios de livros censurados" [Book censorship reports] comprises 10,011 reports, and their digitalised images are also available online. ${ }^{6}$ It should be remarked, though, that $22.4 \%$ of the reports are still missing from the Archives, which constrains research to a great extent. Nonetheless, it is reasonable to expect that the missing archival documents will be located in the near future. ${ }^{7}$

\footnotetext{
${ }^{6}$ The project is a joint venture between two Portuguese research centres: the Research Centre for Communication and Culture (CECC) http://cecc.fch.lisboa.ucp.pt/en/ and the University of Lisbon Centre for English Studies (CEAUL) http://www.ulices.org/home.html. The principle objective of the project is to collect and process information concerning translation production in Portugal between 1930 and 2000. The database is accessible free of charge at http://www. translatedliteratureportugal.org/ (accessed 30 November, 2017).

${ }^{7}$ http://digitarq.arquivos.pt/details?id=4331832 (accessed 30 November, 2017).

${ }^{8} \mathrm{~A}$ small number of reports that were believed to have belonged to the National Archives collection were recently published in the Portuguese politician, José Pacheco Pereira's internet blog (consult at See: https://ephemeraipp.com/indices-especificos/indice-nucleo-da-censura/(accessed 30 November, 2017).
} 


\section{Findings}

The results of the present analysis have been, in part, published as a book chapter in Queering Translation, Translating the Queer, edited by Brian James Baer and Klaus Kaindl (GOMBÁR, 2018). However, as the corpus adopted in the aforementioned study has been extended -approximately 500 Anglophone literary works were added - after checking against the bibliographical databases, a limited, but relevant - additional number of homosexual-themed translations were found (cf. Table 1). The overwhelming majority are Portuguese renderings (9), only one extra Hungarian translation was found. Even if the new findings do not alter the main conclusions concerning homosexual-themed translations published in the period, they might help to highlight certain already prevailing tendencies. 


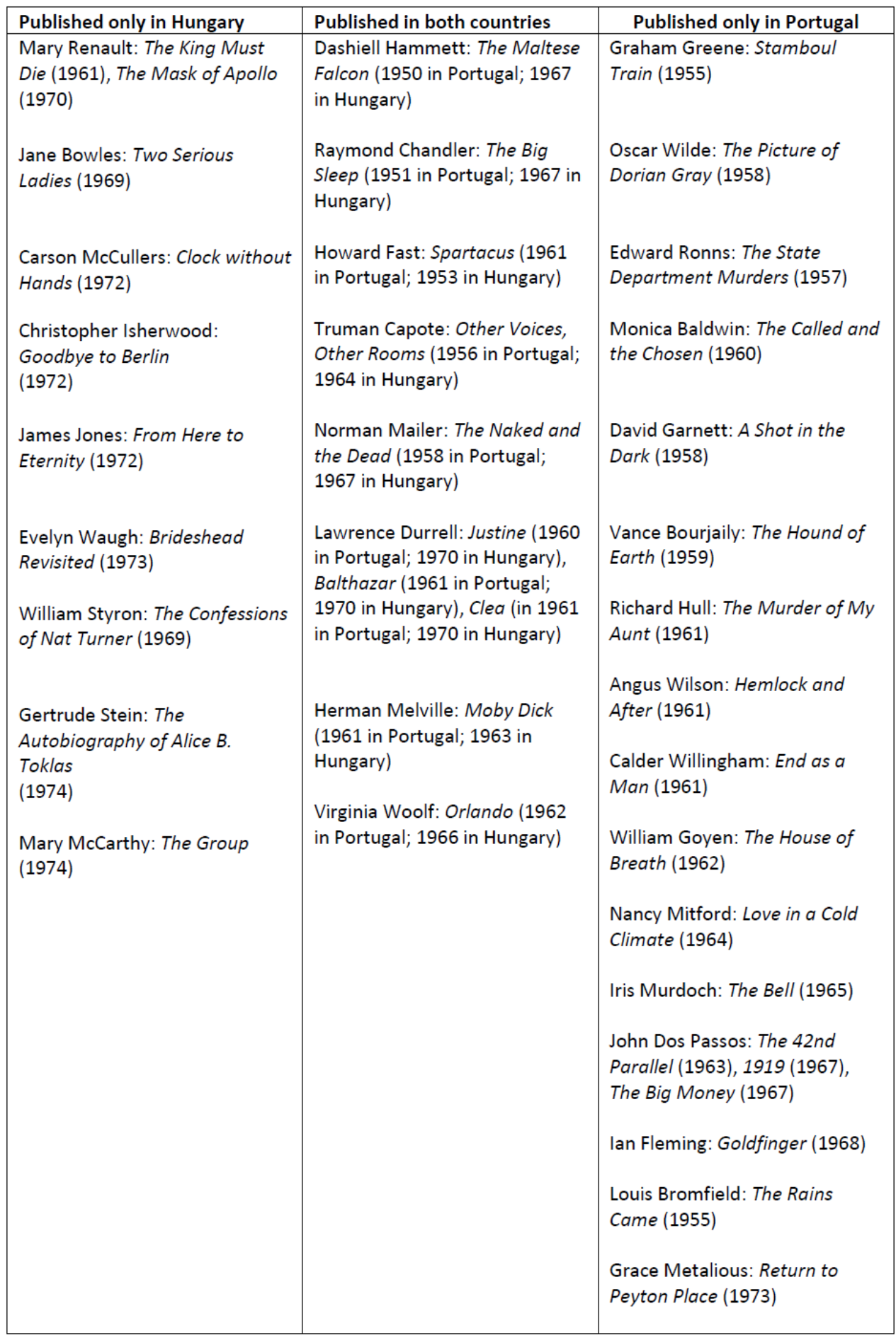

Table 1. Literary translations with homosexual contents published in Portugal and Hun- 
The corpus of homosexual-themed works in English checked against the Portuguese and Hungarian bibliographical records exceeds 900 entries. Even so, the number of novels published in Estado Novo Portugal (28) and state-socialist Hungary (20) is very low. The shortage of Anglophone gay and lesbian themed literary works in Portugal and Hungary clearly implies that the circulation of works with homosexual contents was suppressed in both countries. On the other hand, besides the permanent and menacing presence of state censorship, the low number of translations could be interpreted as a natural consequence of the deep-seated homophobia of the contemporary reading public.

Most intriguingly, a comparison between the documented censorship cases regarding literary translations from English shows equal leniency on the part of the Portuguese and Hungarian book controlling apparatuses. The apparent indulgence, however, could be put down to internalised censorship practices rather than to the political gatekeepers' open-mindedness. The Hungarian reader's reports are quite clear: pornographic descriptions either referring to heterosexual or homosexual sex acts were not allowed to be published including The Wild Boys, The Ticket that Exploded by William S. Burroughs or Numbers by John Rechy.

It is important to note that in Portugal with the exception of Fast's Spartacus whose homosexual scenes were deleted at the censor's requests, no literary works were censored merely on the grounds of their homosexual content (R6942/61). Carson McCullers' Clock without Hands (R7606/65), Pamela Moore's Chocolates for Breakfast (R6204/58), John Updike's Couples (R8490/69) were banned only partly for containing references to homosexuality, but for their supposedly immoral character. Like in Hungary, the pornographic novel Fanny Hill by John Cleland was prohibited and confiscated mostly because of its graphic descriptions of heterosexual sexual adventures and of male as well as female genitals (R9095/71). 


\begin{tabular}{|l|l|}
\hline $\begin{array}{l}\text { Censored in Hungary on grounds of } \\
\text { homosexuality }\end{array}$ & $\begin{array}{c}\text { Censored in Portugal on grounds of } \\
\text { homosexuality }\end{array}$ \\
\hline $\begin{array}{l}\text { Banned: } \\
\text { William S. Burroughs: The Wild Boys, } \\
\text { The Ticket that Exploded }\end{array}$ & $\begin{array}{l}\text { Banned: } \\
\text { John Updike: Couples } \\
\text { John Rechy: Numbers }\end{array}$ \\
John Cleland: Fanny Hill & $\begin{array}{l}\text { Pamela Moore: Chocolates for Breakfast } \\
\text { John Cleland: Fanny Hill }\end{array}$ \\
& Blue-pencilled: \\
& Howard Fast: Spartacus \\
\hline
\end{tabular}

Table 2. Literary translations with homosexual contents censored in Estado Novo Portugal and state-socialist Hungary

The most important difference between the two censorship systems with reference to homosexual representations is that contrary to Portugal, in Kádár-regime Hungary, portrayals or allusions to same-sex love or behaviour alone would not justify prohibition of the work in question. The Hungarian readers were contractually required to inform the publisher in their reports about any ideologically or morally problematic detail (e.g. critical attitude towards the USSR or pornography) of the work in question that would possibly arouse official disapproval and eventually impede the publication of the work. The literary author's sexual orientation, obvious homosexual characters or scenes might be indicated in the reports, but not on a compulsory basis, and almost never presented as a factor impending for publication.

Unlike Hungary, Portuguese authorities were evidently unaware of the homosexual "threat" of these translations, and seemingly did not interfere in their circulation. Paradoxically, it appears, as Baer also notes, that due to the invisibility of homosexuality under dictatorial regimes along with the complete ignorance of the general public about homosexual lifestyle and behaviour, a great number of literary works escaped the censors' attention (BAER, 2010, pp. 25-26). By way of illustration, out of the 28 Portuguese translations under scrutiny, only 8 were subject to censorship: The Picture of Dorian Gray (R2204/43), The 42nd Parallel (R4110/49), 1919 (R699/38), The Big Money (R4111/49), The Rains Came (R5377/55), Return to Peyton Place (R6781/61), Spartacus (R6942/61), and Love in a Cold Climate (R9170/71). However, with the exception of the censorship 
report on Spartacus (R6942/61), none of the reports made concrete reference to homosexual contents.

Furthermore, as already noted, post-publication censorship was a far less reliable control method than pre-publication censorship in Hungary. In the absence of prior restraint, Portuguese publishers could more easily take the risk of publishing controversial literature, as the censors could not possibly devote close attention to every single book published in the country (SERUYA, 2010, p. 138). The lack of prior censorship in Portugal as contrasted to tightly controlled publishing model in Hungary reveals that the regime's cultural administration did not seem to devote considerable attention to literature, especially not in a country where the illiteracy rate continued to be significantly high throughout the era.

Nonetheless, based on paratextual and further archival analysis, it seems that despite legislation in force, from the mid-1960s, referring to homosexuality in literary works would not always imply an automatic ban in Portugal. For example, according to the censorship report on a Brazilian translation on Maximilian Jacta's book on Oscar Wilde's criminal trial, the subject matter alone would not evoke any objection, but as the introduction contains apologetic propaganda with respect to homosexuality, the book should be prohibited (R8520/69). Likewise, the blurb of Portuguese translation of The Picture of Dorian Gray published by publishing house Verbo in 1971 openly refers to Oscar Wilde's imprisonment for homosexuality (cf. WILDE 1971).

The paucity of lesbian-themed novels in both countries is also most remarkable. Although Portuguese translations with recognisable lesbian characters (8) may slightly outnumber the Hungarian ones (4), the portrayals almost without exception are of minor importance and merely used to give local colour to the storyline in the Portuguese translations. Unlike the more positive than neutral representations in Hungary, in Portugal the majority of the fictional characters are negative and repugnant figures such as the predatory Mable Warren in Graham Greene's Stamboul Train. The ghost-like status of lesbians in Estado Novo Portugal as Klobucka terms it (following CASTLE, 1993) is also well reflected in the literary translation production of the era (cf. KLOBUCKA, 2009). Likewise, it clearly indicates the marginalised position of women as well as the social invisibility of lesbians within both the dominant culture and homosexual subcultures (cf. TAKÁCS 2015). 
As expected, none of the novels is a proud programmatic proclamation of homosexuality. Given the restricted period under scrutiny, all works investigated in this study are still products of the pre-Stonewall era and consequently, the majority of them are still closeted texts. Therefore, categories such as "performative role" and "products of sexual minorities" as suggested by Reed do not apply here. Also, similarly to the Portuguese translations with lesbian contents, with the exception of a handful works such as Truman Capote's Other Voices, Other Rooms or Carson McCullers' Clock without Hands, homosexuality as a theme is only marginally present in the novels. Apparently, inclusion of homosexual characters and scenes, as a rule, serves only a decorative purpose, or used to add to the complexity of the novel.

\section{Conclusion}

The major finding of the analysis has already been published, namely, state-socialist Hungary adopted a more receptive and tolerant attitude towards homosexuality within its legal system as well as in its culture politics. While in Portugal, the literature with homosexual contents, for the most part, passed due to the inconsistencies on the part of the Portuguese censors, in Hungary it was a calculated decision by the cultural administration (cf. GOMBÁR, 2018). On second thought, however, the Portuguese censors' inconsistencies along with the inherent fallacies of the book censorship system might also have been a calculated decision on a higher level after all. For instance, besides several unnoticed literary works with implicit or explicit homosexual references, Peter Shaffer's gay-themed play Five Finger Exercise was staged without any objections in 1966 in the Teatro Estúdio de Lisboa founded by the lesbian couple, Luzia Maria Martins and Helena Félix (ALMEIDA, 2010, p. 121).

All in all, despite the Portuguese regime's comparatively more hostile attitude towards same-sex practices, just like in socialist Hungary, there was a hidden and hitherto unexplored gay and lesbian life, which was indeed tolerated to a certain degree. The present article, therefore, aimed to contribute to this hidden part of homosexual history by mapping queer literary translations in Estado Novo Portugal and socialist Hungary. Evidently, the number of unanswered questions is still large. Besides, what was translated, it is essential to know how the original 
text was translated-whether homosexual references were deleted, attenuated, or kept-for whom it was translated, who was the target audience-destined for general or homosexual readers, etc. However, at this stage, the present research is confined to exploring the historical, political and sociological context of translated homosexual-themed literature. The unhidden objective of this study was also to set a humble example, and invite further research for broader comparison.

\section{Reference works}

ALBUQUerQUe, Paulo Pinto de. A Reforma da Justiça Criminal em Portugal e na Europa. Coimbra: Almedina, 2003.

ALMEIDA, São José. Homossexuais no Estado Novo. Porto: Sextante, 2010.

BAER, Brian James. "Queer in Russia: Othering the Other of the West." In Queer in Europe: Contemporary Case Studies, edited by Lisa Downing and Robert Gillett, London: Routledge, 2011, p. 172-188.

BAER, Brian James. "Translating Queer Texts in Soviet Russia." Translation Studies. 4 (1): 21-40, 2010. DOI: 10.1080/14781700.2011.528680

BÁNHEGYI, Zsolt. comp. British Books in Hungary: 1945-1978. Budapest: Hungarian Publishers' and Booksellers' Association, 1979.

BÁNHEGYI, Zsolt. comp. American Books in Hungary: 1945-1987. Budapest: Hungarian Publishers' and Booksellers' Association, 1988.

BARRETO, António and MÓNICA, Maria Filomena. eds Dicionário de História de Portugal. Volume de actualização (1926-1974). Oporto: Livraria Figueirinhas, 1999.

BART, István. Világirodalom és könyvkiadás a Kádár-korszakban. Budapest: Scholastica, 2000.

Biblioteca Nacional. Boletim de bibliografia portuguesa. Lisbon: Biblioteca Nacional, 1935-1977.

BRADLEY, Marion Zimmer. A Complete Cumulative Checklist of Lesbian Variant and Homosexual Fiction. Lexington, Ky.: Emero, 2012.

CARBERY, Graham. Towards Homosexual Equality in Australian Criminal Law: A Brief History. Parkville: Australian Lesbian and Gay Archives, 2010. http://www.alga.org.au/ files/towardsequality2ed.pdf (accessed 30 November, 2017)

CASCAIS, António Fernando. "A homossexualidade nas malhas da lei no Portugal dos séculos XIX e XX." International Journal of Iberian Studies. (29) 2: 95-112, 2016. DOI: 10.1386/ijis.29.2.93_2 
CASTLE, Terry. The Apparitional Lesbian: Female Homosexuality and Modern Culture. New York: Columbia University Press, 1993.

DRAKE, Robert. The Gay Canon: Great Books Every Gay Man Should Read, New York: Doubleday-Anchor, 1998.

EQUALDEX, LGBT knowledge base: http://www.equaldex.com/ (accessed 30 November, 2017)

ESZENYI, Miklós. “Adalékok a homoszexualitás középkori történetéhez" Valóság (1): 4356, 1999.

GOMBÁR, Zsófia. "Literary Censorship and Homosexuality in Kádár-Regime Hungary and Estado Novo Portugal." In Queering Translation, Translating the Queer: Theory, Practice, Activism, edited by Brian James BAER and Klaus KAINDL, New York: Routledge, 2018, 144-156.

GOMBÁR, Zsófia. 2011. "Dictatorial Regimes and the Reception of English-Language Authors in Hungary and Portugal." In Censorship across Borders: The Reception of English Literature in Twentieth-Century Europe, edited by Catherine O'LEARY and Alberto LÁZARO, Newcastle upon Tyne: Cambridge Scholars Publisher, 2011, 105-128.

GRAU, Günter and SCHOPPMANN, Claudia. Hidden Holocaust: Gay and Lesbian Persecution in Germany 1933-45. Translated by Patrick Camiller. Chicago: Fitzroy Dearborn, 1995.

GUNN, Drewey Wayne. Gay American Novels, 1870-1970: A Reader's Guide. Jefferson, North Carolina: McFarland \& Company, 2016.

GUNN, Drewey Wayne. Gay Novels of Britain, Ireland and the Commonwealth, 1881/1981: A Reader's Guide. Jefferson, North Carolina: McFarland \& Company, 2014.

GUNN, Drewey Wayne. The Gay Male Sleuth in Print and Film: A History and Annotated Bibliography. Lanham: Scarecrow, 2013.

HEALEY, Dan. Homosexual Desire in Revolutionary Russia: The Regulation of Sexual and Gender Dissent. Chicago: University of Chicago Press, 2004.

HURLEY, Michael. A Guide to Gay and Lesbian Writing in Australia. St. Leonards: Allen \& Unwin, 1996.

Intercultural Literature in Portugal 1930-2000: A Critical Bibliography. www.translatedliteratureportugal.org/eng/index.htm (accessed 30 November, 2017).

KLOBUCKA, Anna M. (12 September 2009). Summoning Portugal's Apparitional Lesbians: A To-Do Memo (Speech). Association of British and Irish Lusitanists. Maynooth, Ireland: National University of Ireland, 2009 https://www.academia.edu/190256/ Summoning Portugal s Apparitional Lesbians A To-Do Memo (accessed 30 November, 2017).

KNOBEL, Paul. The Male Homosexual, Gay and Queer Novel in Australia: An Annotated Bibliography. Randwick [N.S.W]: Burke and Wills Press, 2010. 
KONTLER, László. Millennium in Central Europe. A History of Hungary. Budapest: Atlantisz, 1999.

KORNETIS, Kostis; KOTSOVILI, Eirini and PAPADOGIANNIS, Nikolaos. Consumption and Gender in Southern Europe since the Long 1960s. London: Bloomsbury Publishing, 2016.

Külföldi szerzők müvei Magyarországon: 1945-1970. Budapest: Könyvkiadók és Könyvterjesztők Egyesülése, 1971.

Külföldi szerzők müvei Magyarországon: 1971-1975. Budapest: Könyvkiadók és Könyvterjesztők Egyesülése, 1977.

KURIMAY, Anita and TAKÁCS, Judit. "Emergence of the Hungarian Homosexual Movement in Late Refrigerator Socialism." Sexualities 20 (5-6): 585-603, 2017. DOI: 10.1177/1363460716665786.

PAYNE, Stanley. G. A History of Fascism, 1914-1945. London: University of Wisconsin Press, 1996.

PINTO, António Costa and KALLIS, António, eds. Rethinking Fascism and Dictatorship in Europe. Basingstoke: Palgrave Macmillan, 2014.

PINTO, António Costa. Salazar's Dictatorship and European Fascism: Problems of Interpretation. Boulder: Social Science Monographs, 1995.

PLANT, Richard. The Pink Triangle: The Nazi War against Homosexuals. New York: A New Republik Book, 1986.

PORBASE. "The Portuguese Union Catalogue." Available online at http://porbase.bnportugal.pt/ (accessed 30 November, 2017).

PRYDE, Dee. "Lésbicas Portuguesas no Século Vinte: Apontamentos para a História." Revista Crítica de Ciência Sociais. 89: 127-139, 2010. Electronic version. http://rccs. revues.org/3746 DOI: 10.4000/rccs.3746 (accessed 30 November, 2017).

RAYTER, Scott; FITZGERALD, Maureen; MCLEOD, Donald W., and Library Thomas Fisher Rare Book. Queer CanLit: Canadian Lesbian, Gay, Bisexual, and Transgender (LGBT) Literature in English: An Exhibition. Toronto: Thomas Fisher Rare Book Library, 2008. Reader' Reports stored at the Archives of Petőfi Literary Museum in Budapest, Hungary. REED, Christopher. Art and Homosexuality. A History of Ideas. New York: Oxford University Press, 2011.

ROBINSON, Shirleen. ed. Homophobia: An Australian History. Annandale, NSW: Federation Press, 2008.

ROSAS, Fernando, ed. Portugal e o Estado Novo (1930-1960). Lisbon: Presença, 1992. Vol. 12 of Nova História de Portugal. eds Joel Serrão and A. H. de Oliveira Marques. 10 vols. 1992-1993.

SANTOS, Ana Cristina, and FONTES, Fernando. "O Estado português e os desafios da (homo)sexualidade." Revista crítica de ciências sociais 59:173-194, 2001. 
SERUYA, Teresa. "Translation in Portugal during the Estado Novo Regime." In Translation under Fascism, edited by Christopher RUNDLE and Kate STURGE. London: Palgrave Macmillan, 2010.

SLIDE, Anthony. Lost Gay Novels: A Reference Guide to Fifty Works from the First Half of the Twentieth Century. Hoboken: Taylor \& Francis, 2013.

SPURLIN, William J. Lost Intimacies: Rethinking Homosexuality under National Socialism. New York: Peter Lang, 2009.

TAKÁCS, Judit, and TÓTH, Tamás P. “Az "idegbizottság” szerepe a homoszexualitás magyarországi dekriminalizációjában." Socio.hu Társadalomtudományi Szemle 6 (2):207223, 2016.

TAKÁCS, Judit; KUHAR, Roman, and TÓTH, Tamás P. "Unnatural Fornication" Cases Under State-Socialism: A Hungarian-Slovenian Comparative Social-Historical Approach." Journal of Homosexuality 64 (14):1943-1960, 2017. DOI: 10.1080/00918369.2016.1273719.

TAKÁCS, Judit. "Disciplining Gender and (Homo)Sexuality in State-Socialist Hungary in the 1970s." European Review of History: Revue européenne d'histoire 22 (1):161-175, 2015. DOI: 10.1080/13507486.2014.983426.

TAKÁCS, Judit. "Listing Homosexuals since the 1920s and under State Socialism in Hungary." In Gender in Twentieth-Century Eastern Europe and the USSR, edited by Catherine Baker, 157-170. London: Palgrave, 2017.

TORGAL, Luís Reis. Estados Novos. Estado Novo. Vol. 1. Coimbra: Imprensa da Universidade de Coimbra, 2009.

WILDE, Oscar. O retrato de Dorian Gray. trad. Artur Pereira. Lisbon: Editorial Verbo, 1971. Originally published as The Picture of Dorian Gray. London: Ward Lock \& Co., 1891.

WILLETT, Graham. "The Darkest Decade: Homophobia in 1950s Australia." Australian Historical Studies 28 (109): 120-132, 1997. 